\title{
Professionals' Perspective of Tax Evasion: Some Evidence from Nigeria
}

\author{
Tijani Oladipupo Muhrtala ${ }^{1, *}$, Mathias Ogundeji $^{2}$ \\ ${ }^{1}$ Elizade University, Ilara-Mokin,Ondo-State, 23401, Nigeria \\ ${ }^{2}$ Mathias Gboyega Ogundeji \& Co. (Chartered Accountants and Tax Practitioners),72/82, Kudirat Abiola Way, Suite A1, Humuani \\ Shopping Mall, Oregun, Ikeja, Lagos-Nigeria \\ *Corresponding Author: oladipupotijani@gmail.com
}

Copyright (C) 2013 Horizon Research Publishing All rights reserved.

\begin{abstract}
Tax revenues constitute a major source of income for governments in most countries. However, the increasing concern on the extent of tax evasion has induced a lot of studies in different countries on the amount of unreported incomes and factors accounting for this phenomenon especially in emerging economies. To analyse this topic, Nigeria has been chosen as a reference point. In order to enhance objectivity, an empirical study has been carried out through a structured survey directed at tax professionals. This information was collected in order to explain the determinants of tax evasion. The results show that tax evasion in Nigeria is largely influenced by complexity in the tax structure, perceived financial and economic benefits associated with tax evasion, and lack of trust in governance over financial resource utilization. This outcome suggest that there should be adequate implementation of appropriate recommendations made in this study towards enhancing a better tax policy and improved tax administration in the country. The study also provides information for future research that might contribute to establish the most adequate mechanisms for taxation.
\end{abstract}

Keywords Tax Evasion, Incomes, Tax Professionals, Complexity, Economic Benefits, Nigeria

\section{Introduction}

Many situations involve deception ranging from plagiarism, embellished resumes, or trickery in sports. Examples of substantial deception by economic agents are the concept of tax evasion and social fraud (Slemrod, 2007) [17]. Tax evasion has been given special attention in literature all over the world. From apparently inconsequential acts like fare dodging in public mass transit buses, paying consultancy services fees without requesting a receipt to several unaccounted billions in VAT, companies', and Personal Income Tax fraud. The concept of tax evasion ranges from different facets to the citizenry with less willingness to pay taxes due. According to taxation literature, Elffers et al., 1987 [5] described tax evasion as any attempt/act of deliberately breaking the law with the sole purpose of decreasing taxes. Tax evasion and fiscal corruption have been long universal in history. They are two persistent problems with manifold economic consequences. Over two thousand five hundred years ago, Plato wrote about tax evasion when he posited that the Ducal Palace of Venice has a stone with a hole in it, through which people once informed the Republic about tax evaders (Tanzi, 2000) [18].

Widespread tax evasion reflected in persistent public resistance to pay is seen as an important part of the issues of raising revenue in any part of the world. Taxation literature has suggested that measures which may be used to address the non-payment problem are to build administrative capacity in the tax structure in order to enhance revenue collection Fjeldstad, 2004) [8]. A significant issue for any revenue agency charged with the responsibility for tax collection is to obtain thorough knowledge and understanding of the reasons for taxpayers' non-compliance. Although the measurement of intentional as well as unintentional non-compliance can be extremely difficult as this involves estimating level of uncollected taxes which often by its nature undetected by tax authorities. Nevertheless, the amount of revenue losses resulting from tax evasion is potentially enormous in any economy (Devos, 2008) [4]. Tax burden in both empirical and theoretical studies have been viewed as the major factor responsible for tax evasion and the shadow effect. The cost of tax evasion in many countries has been restricted to the monetary consequences of detection as the cost of the very act of social fraud is highly neglected (Coricelli, 2010) [3].

The enforcement machinery of the Nigerian tax laws seem so absorbent that taxpayers go against them effortlessly. Those responsible for tax administration seem ill-equipped as they often do not possess the requisite skills and capabilities to perform. Hence, they become cynical, discouraged, exasperated and are therefore unproductive (Ogbonna, 2012) [16]. It is undoubted whether the tax 
system in Nigeria is characterized by economic agents who often evade taxes. One of the arguments provided in taxation literature is that the Government of Nigeria rarely utilize proceeds of taxation in providing social amenities for the benefits of taxpayers but rather, has its focus mainly on generating revenue. The system has consequently been characterized with high rate of forgery of tax documentations and other official receipts including tax clearance certificates as well as non-accountability for taxes collected on the part of tax officials (Ogbonna, 2012) [16].

An examination into the Nigerian tax system was driven by the Federal Ministry of Finance which inaugurated a study group in July 2003 to make recommendations towards enhancing the Nations' Tax Policy hitherto characterized by inefficient administration. The aim was to provide a better tax policy blueprint capable of reducing and possibly eliminating tax evasion. The inquiry spanned into 2004 when a private sector-driven Working Group was also constituted. These groups (The Study and Working) addressed both macro and micro economic challenges in tax policy and administration ranging from multiple taxation and higher tax burden, non-availability of comprehensive tax payers database, lack of accountability for tax revenue and its expenditure; lack of clarity on taxation powers of government at all levels; lack of skilled manpower and inadequate funding; aggressive and unorthodox tax collection methods; non-refund of excess taxes paid by economic agents; non-review of tax legislations; lack of specific policy direction for tax matters amongst others. This National tax policy which suffered unnecessary delay before it was eventually approved for implementation by the Federal Executive Council in January 22, 2010 still find the Nigerian tax arrangement significantly characterized by tax evasion practices.

Although, studies have attributed the reasons for tax evasion to several influences in both developed and Less Developed Economies (LDE's), an examination of the tax compliance literature in Nigeria reveal that there is lack of research attention regarding the influence of tax preparers acting as intermediaries between tax authorities and taxpayers. The results of this study will reveal the factors responsible for continuous tax evasion from professionals' point of view in Nigeria years after structuring and restructuring the system. Specifically, the aim of this study is to provide explanations into the dynamics of tax evasion by economic agents in Nigeria as experienced by professional tax preparers in the course of discharging their duties. These practitioners include diverse group of individuals, business structures and professional groups whose activities includes the provision of wide range of tax services on behalf of their clients who are also economic agents owing civic responsibility for taxation. The study shall offer professional explanations for tax evasion with special emphasis on those factors imminent for its reduction and possible elimination. The results of the study shall reveal how and why the advice of tax practitioners either directly or indirectly influences the ethical climate as well as the level of compliance amongst individual tax payers. Ultimately, the research shall further elicit information on the reasons for economic agents' compliance and non-compliance and provide recommendations towards improving the tax system for onward achievement of the goals of taxation in Nigeria.

The rest of this paper is as organized. Section two provides a review of relevant literature examining past studies on tax evasion. Section three is aimed at describing the research methodology while data analysis and interpretation is outlined in section four. This is followed by discussion of results. Finally, section five summarises and concludes the study by providing some tax policy recommendations while making suggestions for future research.

\section{Review of Relevant literature}

Notwithstanding the value, literature in accounting and finance has argued that there is drastic reduction in States budget all over the world because of the practice of tax evasion by economic agents. In a report released by Tax Justice Network in November 2011, Murphy Richard, tax expert and senior advisor on tax matters for the firm reported that the value of tax evasion the world over is in excess of US\$3.1 trillion approximately $5.1 \%$ of global GDP. A synopsis extracted from the report which provided information on the distribution of tax evasion losses across the world is as revealed in Table 1. The report publicized the ratio of declared to undeclared dollars at global level as 1:6 and 1:5 at European level. In addition, it showed the first ten countries of the world facing the most severe losses due from tax evasion as adapted in Table 2.

Table 1. Tax Evasion across continent

\begin{tabular}{|c|c|c|c|}
\hline Continent & GDP(bn \$) & Average & $\begin{array}{c}\text { Tax Evasion } \\
\text { bn \$ }\end{array}$ \\
\hline & & Shadow & \\
\hline Europe & $18,974,416$ & 20.50 & $1,511,714$ \\
\hline Africa & $1,383,070$ & 34.80 & 79,235 \\
\hline Asia & $19,338,826$ & 17.70 & 665,930 \\
\hline North America & $17,376,075$ & 10.80 & 452,828 \\
\hline South America & $3,632,841$ & 36.80 & 376,298 \\
\hline Oceania & $1,064,690$ & 14.10 & 46,435 \\
\hline
\end{tabular}

Source: Adapted from Murphy, R., (2011) [15].

\subsection{Tax Evasion reported in Empirical Studies}

From developed markets to emerging economies, literature on tax economy has evolved over the years. Some of these studies include that conducted in U.S. (Rego, 2008; McGee \& Smith, 2006; Etzioni, 1986; Desai \& Dharmapala, 2006; McGee \& Gelman, 2009; Decicca et al., 2010; Torgler et al., 2008; and Crane \& Nourzad, 1990); Bangladesh (Bhuiyan, 2012); Russia (Trehub \& Krasnikova, 2006); China (Fisman \& Wei, 2003); India (Wadhwa \& Pal, 2012; 
Ostwal \& Vijayaraghavan; McGee \& George, 2008); Tanzania (Fjeldstad, 2004); Turkey (Yalama \& Gumus, 2013); Italy (Chiarini et al., 2013); France (Coricelli et al., 2010); Israel (Romanov, 2006); Germany (Schmidt \& Cologne, 2007);Norway (Sandmo, 2004); Albania and Netherlands (Gerxhani \& Schram, 2003). Others are Iran (Abassi \& Heidaryemady, 2012); Greece (Matsaganis \& Flevotomou, 2009); Armenia (McGee \& Gelman, 2009); Puerto Rican (McGee \& Lopez-Palau, 2008); Zimbabwe (Hove, 2012); Malaysia (Tabandeh et al., 2012); Turkey and Kyrgyzstan (Sezgin et al., 2011); Australia (Devos, 2008); Kenya and Tanzania (Levin \& Widell, 2007) and Pakistan (Mughal \& Akran, 2012). Here in Nigeria are Ogbonna (2010) and Adediran et al., (2012).

Table 2. Top Most Severe Economies in Tax Evasion.

\begin{tabular}{|c|c|c|c|}
\hline Country & GDP(Bn \$) & Average & Tax Evasion \\
\hline & & Percentage & Bn \$ \\
\hline & & Shadow & \\
\hline USA & $14,582,400$ & 8.60 & 337,349 \\
\hline Brazil & $2,087,890$ & 39.00 & 280,111 \\
\hline Italy & $2,051,412$ & 27.00 & 238,723 \\
\hline Russia & $1,497,819$ & 43.80 & 221,023 \\
\hline Germany & $3,309,669$ & 16.00 & 214,996 \\
\hline France & $2,560,002$ & 15.00 & 171,264 \\
\hline Japan & $5,497,813$ & 11.00 & 171,147 \\
\hline China & $5.878,629$ & 12.70 & 134,385 \\
\hline UK & $2,246,079$ & 12.50 & 109,216 \\
\hline Spain & $1,407,405$ & 22.50 & 107,350 \\
\hline
\end{tabular}

Source: Adapted from Murphy, R., (2011) [15].

Earlier studies in the U.S. by Etzioni (1986) [6], addressed the debate as to whether tax evasion results from increased tax rates and economic incentives as claimed by several economic scholars. Using survey data collected between 1960 and 1980, the author found that tax evasion increased during the periods as most Americans considered taxes as unfair even though tax rates remained stable. The information gathered in the survey led the author to conclude that the growing sense that taxes are unfair is more likely than increasing tax rates and one's level of income to lead to tax evasion. This position was corroborated by Fisman and Wei (2003) [8] when they examined tax evasion in China by comparing the values of the country's imports from Hong-Kong, with what Hong-Kong reported as exports to china over a defined period. The result was that on average, a $1 \%$ increase in tax rate is accompanied by a $3 \%$ escalation in evasion. However, there was a non-linear correlation as evasion elasticity is larger at higher tax levels. In a related study, Levin and Widell (2007) [11] estimated the amount of tax evasion in customs authorities in Kenya and Tanzania by calculating measurement errors with tax rates through evidence from missing imports. Findings concluded that coefficient on tax is higher in Tanzania as compared to Kenya, implying that tax evasion on imported goods is higher in Tanzania than Kenya and ultimately tax evasion is more severe in the Tanzanian customs authority. Ultimately, corruption amongst tax officials and lack of transparency in tax revenue accountability are responsible for tax evasion in these countries.

Another empirical investigation conducted by Abbasi and Heidaryemadi (2012) [1] using input from 1300 questionnaire distributed across officials in employees and legal persons, provided evidence to factors responsible for tax evasion in Iran through field investigation. Findings discovered several motives for tax evasion ranging from mistrust and unfairness perception of tax system, lack of transparency in tax rules, lack of sanctions for tax collection, inadequate technological infrastructure to support the tax system, inept and inexperience tax officials, precipitate and reckless approval of some tax rules; lack of trust about destination of tax revenues and lack of adequate accounting records by economic agents. Fjeldstad (2004) [8] in Tanzania also supported this view when his study concluded that citizens feel they get very little in comparison with taxes paid. The study revealed that this perception has impact on their willingness to pay as well as contribute to eroding peoples' trust in the local government's capacity to provide expected services. Hence, the study suggested the provision of better linkage between tax compliance and service delivery as majority of respondents do not have any form of information about local government finances.

An exploratory study in Australia carried out by Devos (2008) [4] investigated the relationship between demographic variables and personal taxpayers' attitudes to tax evasion. The electronic survey of 300 respondents revealed that the link between taxpayers' attitudes towards penalties and the consequential attitude towards tax compliance is dependent on a number of factors such as the imposition of penalties, gender, occupation as well as age of respondents. In a series of experiments among different social groups in both Albania and the Netherlands to compare behavioural patterns related to tax evasion, Gerxhani and Schram (2003) [9] found that economic agents take the possibility of evasion into cognizance when deciding on the source of income, where one type enables subsequent tax evasion. In addition, there exist no distinct levels of tax evasion in both countries in relation to attitudes and culture as the research attributed tax evasion in Albania to inadequate tax collection institutions, while audit probability plays significant role in the Netherlands.

In defining effective strategies to curb tax evasion with the Beitbridge border post in Zimbabwe, Hove (2013) [10] conducted a survey on the Zimbabwe revenue Authority (ZRA) officials and its clients. The paper revealed factors such as high tax threshold and lack of transparency in tax revenue appropriation hold ace for tax evasion. A study on tax evasion in Greece was also carried out by Matsaganis and 
Flevotomou (2010) [12] reflecting an estimated $15 \%$ of tax evasion in the country. Comparing income reported in tax returns with those observed in the household budget survey in 2004/05, the paper discovered income under-reporting in Greece at $10 \%$, resulting in a $26 \%$ shortfall in tax receipts and concluded that the impacts of tax evasion are higher income inequality and poverty, as well as lower progressivity of the income tax structure. The findings further revealed factors responsible for tax evasion ranges from low trust in Governance and low tax morale. One other survey conducted on tax evasion was in Armenia as reported by McGee (2006) [13] where he presented the outcome of an empirical study amongst Armenia theology and business students in 2005. The paper found that there is widespread moral support for tax evasion in Armenia. Mughal and Akram (2012) [14], in an empirical investigation similarly conducted an enquiry into factors responsible for tax evasion in Pakistan and discovered that lack of public enlightenment, inadequate tax incentives, poor relationship between taxpayers' and authorities', proliferation and/or multiplicity of taxes, illiteracy of tax calculation ranked amongst the top the list.

In a slightly differing approach, Tabandey et al., (2012) [19] applied Neural Network method and used multilayer perceptron layer (MPL) with 5 factors for the input layer to determine the factors affecting tax evasion and their relative contribution by sign data from 1963 to 2010 in Malaysia. Results discovered strong negative correlation between individual taxpayer's income and tax evasion which depends largely on tax rates. After increasing income, if government increases tax rates, taxpayers' action is to avoid tax and tax evasion would be on the rise. One sharp point to note in this study is that there was no form of difference between the uses of the term tax evasion as compared to tax avoidance as they both were used interchangeably in the paper.

Using similar approach to that adopted in this study, Wadhwa and Pal (2012) [20] in India surveyed the opinion of income tax professionals' regarding income tax evasion. Their concluded was that high tax rates, corruption in public sector units, multiple tax rates and inefficient tax authorities were largely blameable for tax evasion in India and suggested significant reduction in tax rates, simplification of tax laws as well as removal of loopholes in the tax laws. In addition, they recommended proper information processing under applicable tax returns computation, creation of transparent, friendlier and less discriminatory administrative system, educating the public about tax laws in the country in order to reduce tax evasion. In Turkey, one of the reviews on tax evasion was aimed at investigating factors related to tax evasion (Yalama \& Gumus, 2013) [21]. The survey employed factor analysis and multiple regression techniques and discovered that taxation and fiscal factors, demographic, administrative and few other factors have statistically significant effect on tax evasion behaviour of Turkish residents.

\section{Method and Data}

\subsection{Population and Sample Size}

Empirical evidence has revealed that the issue of tax avoidance cut across all economies of the world. From developed economies as U.S., France, U.K., Germany, Spain, Italy, Japan with organized financial markets down to fast developing markets such as the BRICS of Brazil, Russia, India, China and South-Africa to other Less Developed Environments including Ghana, Ethiopia, Cameroun, Zimbabwe and Nigeria amongst others where financial activity is relatively small. Nigeria was chosen to conduct the investigation of professionals' perspective of factors responsible for tax avoidance. This is a country where the tax regulation is lax, complex and inefficient. Many other developing countries present similar circumstances.

This study was found upon information obtained as input from sampled representatives of tax professionals in the country with particular emphasis on Lagos- State. These tax professionals within this context are used to mean tax practitioners covering diverse groups of individuals, business structures and professional groups who provide a range of services for their clients. A handful of them are self-employed and in-house accountants, tax advisors as well as registered consultants and tax agents, franchisees and legal practitioners in tax capacity.

\subsection{The Survey Instrument}

The survey instrument encompassed 4 sections and 20 questions, of which there are many parts to most questions and a space at the concluding section for additional comments. For the purpose of providing answer to the objectives envisaged in the study, 20 of these questions have direct relevance. A 5 point Likert-scale was employed with scales ranging from "least influential" denoted with 1 to "extremely influential" represented by 5 , with moderate scores amid the two extremes.

\subsection{The Survey Sample}

The sample consists of 160 tax professionals acting in tax preparers' capacity. This list includes tax practitioners, tax agents, tax accountants and tax lawyers. An examination of the role of tax professionals' as tax preparers has been taken from the perspective of both tax preparers' themselves and from the perspective of taxpayers. This representative best serve a dual purpose for the resolve of this study.

\subsection{The Survey}

The structured survey was designed based on the questionnaire designed for the study. Several filter questions were included for certain category of subjects considered important such as the degree of qualification, field 
experience as well as their perception of the existing tax structure. The Likert scale adopted was also used with metric and dichotomous questions to analyse the variables and also to evaluate precise conditions existing. Internal consistency was estimated using Cronbach's Alpha coefficient, which had a value computed at 0.768 in pilot survey hitherto conducted. The field work span between March to May, 2013.when the items in the questionnaire were evaluated, the Cronbach's Alpha coefficient of 0.835 was obtained while the sampling error was computed at $9.73 \%$ and considered acceptable for the investigation as no known parameters previously exist.

In the first place, preliminary analyses were performed using survey tabulation. This was used to gather results in accordance with the topic of interest. Subsequently, it allowed comparative analysis as well as contrast the tendencies of different variables under investigation.

Secondly, a multivariate analysis was conducted to explore the degree of dependency between the binary dependent variable that was "contact with tax evaders" and "no contact with tax evaders" in Nigeria from respondents' experience "on-the-job", and 20 other independent variables, which were determined empirically. To examine the influence of those factors on the dependent variable, a logistic regression was applied, making use of the stepwise procedure as a significant predictor in each of the regressions preformed.

Table 3. Questionnaire Distribution and Responses.

\begin{tabular}{|c|c|c|c|}
\hline Respondent & Number of & $\begin{array}{c}\text { Number of } \\
\text { Responses }\end{array}$ & $\begin{array}{c}\text { \% of } \\
\text { Responses }\end{array}$ \\
\hline Group & Survey & & \\
\hline Tax Advisors & 40 & 22 & $55.0 \%$ \\
\hline $\begin{array}{c}\text { Registered } \\
\text { Consultants }\end{array}$ & 40 & 19 & $47.5 \%$ \\
\hline $\begin{array}{c}\text { Tax } \\
\text { Accountants }\end{array}$ & 40 & 28 & $70.0 \%$ \\
\hline Tax Layers & 40 & 18 & $45.0 \%$ \\
\hline Total & 160 & 87 & $54.4 \%$ \\
\hline
\end{tabular}

Source: Analysis of survey Data (2013).

\section{Data Analysis and Interpretation}

Respondents were categorized into four. This list include tax professionals acting in tax advisory, registered consultants, tax accountants and legal practitioners acting in tax lawyers capacity. Out of the one hundred and sixty (160) copies of questionnaire administered, a total of eighty-seven (87) copies were returned, completed in full and found exclusively sufficient for the purpose of analysis. This represents an overall response rate of $54.4 \%$ for all groups. These responses were subsequently used to provide answers to the questions raised in the study. Table 3 presents information on the responses of each group of respondents.

Amongst respondents surveyed, 22 were professional tax advisors, 19 were registered tax consultants, 28 tax accountants while 18 tax lawyers responded to the inquiry totalling 87 . Of this figure, 64 (representing $74 \%$ ) agreed that they have experience with tax evaders. 22 were tax accountants, 16 tax advisors, 11 tax lawyers and 15 registered consultants.

\subsection{Multivariate Statistical Analysis}

After obtaining the 15 independent variables the $\mathrm{KMO}^{2}$ index was calculated at 0.675 . Thereafter, communalities were taken into account in verifying the effectiveness. Subsequently, the main components were calculated, resulting that the first 5 variables, which explained the $72.616 \%$ of observed total variance of the 15 variables presented eigenvalues major than the unit, satisfying the criterion to identify number of factors therein. Taking into account the correlations between factors and variables, the factors were interpreted and named accordingly.

The first components comprises the variables concerning high tax rates, complexity of the existing tax system, lack of adequate enforcement of defaulters, inefficient and equitable tax and low probability of detection. This component factors was established as viability of the operations of the tax arrangement, identifying it as "Tax Structure".

The second category of variables comprises the illiteracy of tax calculation, inadequate public enlightenment and low tax awareness and was identified as "Knowledge of the existing tax system". The third component clusters variables related to lack of adequate tax incentives, distribution from the provision of public goods, perceived incidence effect of tax burden and perceived financial benefit of tax evasion, and is accordingly classified under "Financial and Economic Motives". The fourth variables embraced absence of tax morality, proliferation of taxes, religiosity, and unfairness in tax collection processes, lack of commitment by taxpayers and greed and corruptive practices of tax officials, all covered under "Ethics".

Among the fifth group of variables, there are those related to lack of trust in Governance over resource utilization, institutional quality (corruption) and inefficient tax administration and bureaucratic bottlenecks, leading to identify the fifth group as "Governance and Administration".

\subsection{Logistic Regression}

The last phase of the study was covered by analysis on logistic regression performed to establish which of the factors had the greatest incidence on tax evasion in Nigeria from the point of view of tax professionals. In order to verify this, the selected dependent and independent variables identified in earlier section were applied. Regarding the independent variables, the resulting values of the factorial analysis were gathered for each one of the 87 observations in the survey according to the elements recorded by the statistical software (SPSS version 18), during the study. In this way, 5 independent variables were obtained analogous to the recognized components. Accordingly, the outcome 
was that the prime variables for the model that presented the most substantial relationship with the dependent variable Tax Evasion) were: (a) Tax Structure (b) Financial and/or Economic Reasons, and (c) Governance and/or Administration. Tables 4, 6, and 8 detailed the results of logistic regression conducted. Consequently, the tax structure, financial and economic benefits associated with tax evasion as well as governance and administrative issues in Nigeria tax system have the most significant influence on tax evasion by economic agents.

\subsection{Comparison with Similar Studies}

A study about the effective strategies to curb tax evasion in Zimbabwe was conducted by Hove (2013). From a similar survey to that applied in this study, factors identified to be responsible for tax evasion were high tax threshold and lack of transparency in the way tax revenues were appropriated, while statistical methods were used in this study to reach similar conclusions. These were related to ones found in this study.

Another survey conducted in Pakistan by Mughal and Akram (2012) was aimed at finding out the reasons for tax avoidance and tax evasion. Top five factors discovered were lack of public enlightenment; lack of adequate tax incentives; poor relationship between taxpayers and authority; proliferation of taxes and illiteracy of tax calculation. These factors are clearly related to those found herein.

\section{Conclusion and Recommendations}

The concept of tax evasion is a general phenomenon the world over, from developed to emerging economies. The Tax Justice network in its 2011 reported that countries like the U.S., Brazil, Italy, Russia, Germany, France, Japan, China, U.K. and Spain faces the most severe losses due from tax evasion. This study drew from tax professionals' perspective to determine the factors primarily responsible for tax evasion by economic agents in Nigeria. Findings revealed that the most significant elements were deficiencies in the existing tax structure; financial and/or economic factors on the part of tax payers and tax governance administrative issues. The importance of regulations, legal and accounting issues in taxation also cannot be overemphasized. In order to reduce these barriers to effective taxation, the leadership must take active steps to ameliorate the situation in order to ensure taxation plays its role as a major source of non-oil revenue.

Tax authorities in the country should engage in practices capable of attracting public confidence and take steps to improve relationship between tax payers and tax officials. The National Tax Policy recommendations must be implemented to the letters as the structure is expected to deliver taxation backed by modern technology tools. Tax evasion should be prevented in a scientific manner, using less human factor with e-government in taxation. Tax payers must be educated about the importance of bookkeeping and accounting records keeping, using professional accountants. Tax institutions could also provide support by setting up procedures to train taxpayers on how to prepare financial records and accounts based on tax laws. This could be supported by the government enacting laws issuing licenses only if such trainings are successfully completed. Taxpayers must be provided with cultural grounds to emphasize the importance of keeping financial records. Students should be trained in collaboration with the Ministry of Education and other groups with the Ministry of Industries, Commerce and the Ministry of Science and Technology. Licenses could also be issued after passing training courses by self-employed individuals who own entrepreneurship businesses.

Tax officials must be educated on etiquettes of good tax culture. They must learn the basic principles and values like respecting citizens, following rules, being trainable and organized as well as having conscience and keeping workplace ethics. They must learn to be confidants to tax payers, impartial, honest, independent and providing high quality services, having job expertise and following national interests as they guide taxpayers.

Labour unions could also be used as a channel to arrange annual personal, distant and written learning courses, in order to make taxpayers familiar with tax rules and regulations. In addition, taxpayers could be provided with brochures covering their responsibilities as regards taxation.

Collaboration among various stakeholders would also be of substantial benefits. Corporate entities, government at all levels including State and Local Government councils, tax practitioners, professional bodies, Ministries of education and consultants should come together to provide educational courses. The media should also be used extensively to promote taxation. Tax laws should be included in all tertiary institutions curriculum for both accounting and non-accounting undergraduates as well as adding the concept of pre-varsity educational books with the cooperation of the Ministry of Education, Ministry of Science, Research and Technology.

Finally, Tax-related offenses must be duly sanctioned, so that taxpayers are aware about the effect of every intended evasion.

\section{REFERENCES}

[1] Abbasi, E., and Heidaryemadi, H., Investigating Causes of Tax Evasion among Employees and Legal Persons, Journal of Basic and Applied Science Research, 2(11), 2012, pp. 11589-11595.

[2] Bhuiyan, H., Tax Evasion and Avoidance Practices in some Selected Corporate firms of Bangladesh, World Journal of Social Sciences, 2(7), 2012, pp. 150-156.

[3] Coricelli, G., Joffily, M., Montmarquette, C., and Villeval, M., Cheating, Emotions and rationality: an experiment on 
tax evasion, Experimental Economics, 13, 2010, pp. 226-247.

[4] Devos, K., Tax Evasion Behaviour and Demographic Factors: An Exploratory Study in Australia, Review Law Journal, 18(1), 2008, pp. 1-43

[5] Elffers, H., Weigel, R.H., Hessing, D.J., The Consequences of Different Strategies for Measuring Tax Evasion Behaviour, Journal of Economic Psychology, 8(3), 1987, pp. 311-337.

[6] Etzioni, A., Tax Evasion and Perceptions of Tax Fairness: A Research Note, The Journal of Applied Behavioural Sciences, 22(2), 1986, 177-185

[7] Fisman, R., and wei, S., Tax rates and Tax Evasion: Evidence from "Missing Imports" in China, Bureau for Research in Economic Analysis of Development (BREAD), 2003.

[8] Fjeldstad, O., To Pay or not to Pay? Citizens views on taxation in Local Authorities in Tanzania, CMI Working Paper, 2004.

[9] Gerxhani, K., and Schram, A., Tax Evasion and the Source of Income: An Experimental Study in Albania and the Netherlands, AIAS Working Paper 03/11, Universiteit van Amsterdam, 2003.

[10] Hove, N., An Investigation on Effective Strategies to Curb Tax Evasion: A Survey of Beitbridge ZIMRA Staff and Clients, Zimbabwe, Elite Research Journal of Accounting and Business Management, 1(1), 2013, pp. 1-9.

[11] Levin, J., and Widell, L., Tax Evasion in Kenya and Tanzania: Evidence from Missing Imports, Working Paper Series, W.P. 8, Orebro University, 2007.

[12] Matsaganis, M., and Flevotomou, M., Distributional Implications of Tax Evasion in Greece, Journal of Taxation and Accounting, 3(4), 2010, pp. 24-27.
[13] McGee, R., Tax Evasion in Armenia: An Empirical Study, Armenian International Policy Research Group, 2006.

[14] Mughal, M., and Akram, M., Reasons of Tax Avoidance and Tax Evasion: Reflections from Pakistan, Journal of Economics and Behavioural Studies, 4(4), 2012, pp. 217-222.

[15] Murphy, R., The Cost of Tax Abuse: A Briefing Paper on the Cost of Tax Evasion Worldwide, The Tax Justice Network, 2011.

[16] Ogbonna, G., Burning Issues and Challenges of the Nigerian Tax Systems with Analytical Emphasis on Petroleum Profits Tax, Journal of Accounting and Taxation, 3(4), 2012, pp. 117-126.

[17] Slemrod, J., Cheating Ourselves: The Economics of Tax Evasion, Journal of Economics Perspectives, 21(1), 2007, pp. 25-48.

[18] Tanzi, V., A Primer on Tax Evasion, Chapter 10 in V. Tanzi Policies, Institutions and the dark side of Economics, Edward Elgar: Cheltanham, 2000, pp. 171-185.

[19] Tabandeh, R., Jusoh, M., Nor, N. and Zaidi, M., Estimating Factors Affecting Tax Evasion in Malaysia: A Neural Network Method Analysis, Prosiding Perkem VII, 2, 2012, pp. 1524-1535

[20] Wadhwa, L., and Pal, V., Tax Evasion in India: Causes and Remedies, International Journal of Applied Engineering research, 7(11), 2012, pp. 117-123.

[21] Yalama, G., and Gumus, E., Determinants of Tax Evasion Behaviour: Empirical Evidence from Survey Data, International Business and Management, 6(2), 2013, pp. $15-23$. 